\title{
The Bodyguard of the Caliphs During the Umayyad and the Early Abbasid Periods
}

\author{
La custodia de los califas durante \\ el Califato omeya y el principio del Califato 'abbāsí"
}

\author{
Yaara Perlman \\ Hebrew University of Jerusalem, Israel
}

During early Islam, the haras was a government unit that was responsible for the personal security of the caliph. Since the reign of the first Umayyad Caliph, Mu'āwiya b. Abī Sufyān, the haras, headed by a haras chief, protected all caliphs. This paper will attempt to describe the functions of the haras during the Umayyad and the early Abbasid caliphates by delineating the characteristics of the haras chiefs under the different caliphs. As with other institutions during early Islam, accounts that refer to the haras offer information about the men who headed it rather than about the institution itself, making it necessary to employ the method of prosopography in order to arrive at an adequate description of the institution. The majority of the haras chiefs appear to have been mawāl $\bar{l}$, often entrusted with administrative offices in addition to heading the haras. It seems that the haras chiefs were responsible not only for protecting the caliphs, but also for carrying out executions. The establishment of the haras, the qualifications of the haras chiefs and the
Durante los principios del Islam el haras fue una unidad del gobierno, responsable de la seguridad personal de los califas. Desde el reinado del primer califa omeya Mu'āwiya b. Ab̄̄ Sufyān, el haras que estaba bajo las ordenes de su jefe, custodió a todos los califas. El propósito de este artículo es describir el papel del haras durante el periodo del Califato Omeya y el principio del Califato Abbasí y describir las características de los jefes del haras bajo los diferentes califas. Al igual que con otras instituciones durante el comienzo del Islam, la información relacionada con el haras se basa en la vida y obra de los hombres que los encabezaban y no tanto en los datos específicos de la institución. Esto hace necesario el uso del método prosopográfico para conseguir una descripción adecuada de la institución. La mayoría de los dirigentes del haras fueron mawālì y muchas veces eran responsables de las funciones administrativas, además de comandar el haras. Sus dirigentes no solo eran responsables de la protección de los califas, sino tambien de ejecutar sus órdenes. Este

* This article is based on a paper written for a course taught by Professor Michael Lecker in the Hebrew University of Jerusalem. I am deeply grateful to Professor Michael Lecker for his guidance and support. I also wish to thank Professor Simon Hopkins for reading and commenting on an earlier draft of this paper, and the anonymous reviewers of this journal for their thorough and very helpful remarks. 
weapons used by members of this body are also discussed. This significant institution has not yet received due attention in the literature. I hope to provide a useful outline and to open up a space for further research.

Key words: Haras; Haras Chiefs; Harasī; Mawlā; Umayyad Period; Abbasid Period. artículo explica también la creación del haras, las cualidades de sus líderes y las armas que utilizaban. Este grupo tan importante ha recibido poca atención por parte de la investigación actual.

Palabras clave: Haras; jefes del haras; harasī; mawlà; Califato omeya; Califato 'abbāsi.

The haras was a unit of bodyguards used by all the caliphs, beginning with Mu'āwiya b. Ab̄̄ Sufyān (r. 41-60/661-680). This paper aims to describe the haras institution on the basis of an analysis of the data concerning the men at the head of this unit during the Umayyad and early Abbasid periods. The method of prosopography, showing that the haras chiefs had much in common, will prove to be necessary in obtaining an adequate description of this early Islamic institution.

Classical Arabic literature abounds in accounts regarding the haras; however this body has not received a thorough discussion. It is not mentioned in the Encyclopaedia of Islam except for brief references in some entries. ${ }^{1}$ Darādkeh's article about the shurța and haras during early Islam deals with both bodies, but does not discuss the haras on its own. ${ }^{2}$

Some studies make some mention of the haras. Hugh Kennedy devotes two pages in his The Armies of the Caliphs to the shurta and haras, yet most of his discussion refers to the shurta. ${ }^{3}$ Studies on the shurta speak of the haras, but typically give it only a few lines. ${ }^{4}$ Patricia Crone mentions the haras in a footnote at the end of her Slaves on Horses. ${ }^{5}$ More to the point, the book contains a prosopographical index with bi-

\footnotetext{
${ }^{1}$ Nielsen, "Shurța," in $E I^{2}$; Crone, "Mawlā," in $E I^{2}$.

${ }^{2}$ Darādkeh, "al-Ḥaras wa-l-shurța fī șadr al-Islām ilā nihāyat al-dawla al-umawiyya," pp. 69-95.

${ }^{3}$ Kennedy, The Armies of the Caliphs: Military and Society in the Early Islamic State, pp. 13-14

${ }^{4}$ Rashid, The Role of the Shurta in Early Islam, pp. 151-55; Donner, "The Shurta in Early Umayyad Syria," pp. 257-58; Ebstein, "Shurț Chiefs in Bașra in the Umayyad Period: A Prosopographical Study," pp. 117-18; Tyan, Histoire de l'organisation judiciaire en pays d'Islam, p. 593. See also: Donner, "The Articulation of Early Islamic State Structures," xxiv-xxv. On a possible Byzantine and Persian origin of the haras see: Rashid, The Role of the Shurta, pp. 7-13.

${ }^{5}$ Crone, Slaves on Horses: The Evolution of the Islamic Polity, p. 248.
} 
ographies of haras chiefs during the early Abbasid period. Haras chiefs of the Umayyad period, however, are rarely mentioned in available studies. Wadād al-Qāọī discusses the haras at several points in her article about security positions under the Umayyads, and she notes: "There is no independent, thorough study on the haras in Umayyad times, but several studies on the shurț (usually translated as police) deal with them." $"$

\section{The Establishment of the Haras}

The use of the term haras in primary sources

The haras was institutionalized during the time of $M u$ 'āwiya $b . A b \overline{1}$ Sufyān, but the term appears in the sources with reference to earlier periods as well. For instance, several men are said to have been in the haras of the prophet Muhammad in his expeditions. ${ }^{7}$ It is not certain that the term haras was in fact used at the time of the prophet; even if it was used, it probably did not denote an organized body but rather groups of people who had volunteered to protect the prophet. It may be noted that some reports do create the impression that the haras at the time of the prophet was indeed an organized institution. ${ }^{8}$ In contradistinction, the haras at the time of Mu'āwiya was undoubtedly a governmental body under the command of the caliph, which escorted and guarded him wherever he went.

The term haras is also used with reference to the time of the rightly-guided caliphs (al-khulafä' al-rāshidūn). Abū Bakr (r. 1113/632-634) is said to have used his haras to protect Medina from at-

\footnotetext{
${ }^{7}$ According to a tradition transmitted by ' $\bar{A}$ 'isha, the prophet had guards until verse 67 of Sūrat al-Mā'ida was revealed: wa-llāh ya 'ṣimuka mina l-nās: Darādkeh, "al-Ḥaras wa-1-shurta," p. 70. For a list of some of the men who are said to have been guards of the prophet see also: Ibn Ḥajar al-'Asqalānī, Fath al-bārī bi-sharh șaḥ̄h al-Bukhārī, XV, p. 136.

${ }^{8}$ For example, the reports according to which the members of the prophet's haras captured some men from Quraysh during the conquest of Mecca: al-Bukhārī, Sahịh al-Bukhārī, IV, p. 1559.
}

${ }^{6}$ Al-Qādī , "Security Positions under the Umayyads: The Story of 'Ma 'bad al-Turuq"” p. 264. 
tack. ${ }^{9}$ Regarding 'Umar b. al-Khaț̣̄a (r. 13-23/634-644), we are told that he did not have a haras. When the captured Persian general alHurmuzān was brought to 'Umar, the former asked where the caliph's guards were. Realizing that 'Umar had no guards, al-Hurmuzān concluded that 'Umar must be a prophet. ${ }^{10}$ The purpose of this tradition, however, seems to have been the portrayal of 'Umar in a positive manner, as a caliph who did not separate himself from the people. Due to the questionable historicity of reports of this kind, it is difficult to be certain that 'Umar indeed did not have bodyguards.

\section{The establishment of the haras by Mu'āwiya}

Most accounts concerning the establishment of the haras have it that Mu'āwiya b. Abī Sufyān founded the body following an attempted assassination. ${ }^{11}$ After this event, Mu'āwiya built a maqșūra (a guarded room for the caliph inside the mosque) that was surrounded by haras members at the time of prayer. ${ }^{12}$ Other accounts concerning this assassination attempt give more details about the behavior of the haras inside the mosque. Al-Dīnawarī remarks that only the haras members and the most trusted men were allowed to enter the maqșura. When Mu'âwiya was praying, ten members of his haras stood behind him armed with swords and clubs ('umud). ${ }^{13}$

Several other accounts agree that the haras was institutionalized

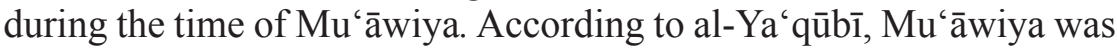
the first to establish the haras, the shurat (pl. of shurta), and the

\footnotetext{
${ }^{9}$ Ibn Kathīr, al-Bidāya wa-l-nihāya, V, p. 188 Darādkeh, "al-Ḥaras wa-l-shurța,” p. 71.

${ }^{10} \mathrm{Al}$-Ṭabarī, Ta'rīkh al-rusul wa-l-mulūk, first series V, pp. 2557-58 (English translation: The History of al-Tabari, XVIII, p. 138).

${ }^{11}$ Darādkeh, "al-Ḥaras wa-l-shurța," p. 89; Morony, Iraq after the Muslim Conquest, p. 93.

${ }^{12}$ Ibn Kathīr, al-Bidāya wa-l-nihāya, VI, p. 10. See also: al-Ṭabarī, Ta' rìkh, first series VI, pp. 3464-65 (English translation: XVII, p. 223), where it is said that after the assassination attempt, $\mathrm{Mu}$ 'āwiya established the maqșūrāt (pl. of maqșūra), haras al-layl (night guard), and ordered the shurta to protect him when he was praying. However, it seems more likely that the haras members rather than the shurta were responsible for the caliph's personal safety inside the mosque, as can be seen in other reports (see below, note 66). For more on the maqșüra see: Pedersen, "Masdjid," in $E I^{2}$.

${ }^{13}$ Al-Dīnawarī, al-Akhbār al-ṭiwāl, pp. 198-99.
} 
bawwābūn (pl. of bawwāb-door keeper), and the first to have people walk in front of him with lances in formal processions. ${ }^{14}$ Further, Mu'āwiya's haras chief - Muslim Abū 'Abd Allāh, a mawlā of Khuzā'a - is said to have been the first person to be put in charge of this body. ${ }^{15}$ Al-Tabarī gives the name of Mu'āwiya's haras chief: alMukhtār or Abū 1-Mukhāriq according to another version (both of whom were mawāl $\bar{l}$ ), and afterwards remarks that Mu'āwiya was the founder of the haras. ${ }^{16}$

Reports concerning the establishment of the haras belong to the genre of $a w \bar{a} ' i l$, and are therefore problematic, since they aim to place the origins of this body in a historical event. ${ }^{17}$ It is therefore noteworthy that some reports indicate that $\mathrm{Mu}$ 'āwiya used bodyguards even before the attempt on his life. Thus, in one report he is said to have been with a guard (haras $\bar{l})$ before he was attacked. ${ }^{18}$ There are also reports according to which the haras chief, Nușayr Abū Mūsā, refused to go with Mu'āwiya to the battle of Siffin. ${ }^{19}$ These reports, where the haras is present in the background, should be considered reliable with regard

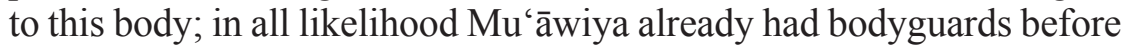
the assassination attempt. It seems plausible, nevertheless, that the haras was indeed institutionalized at the time of $\mathrm{Mu}^{\prime} \bar{a}$ wiya, though not necessarily as a direct result of the attack on him.

\section{The haras of Ziyād b. Abīhi}

Some traditions ascribed the founding of the haras to Ziyād b. Abīhi, the governor of Iraq and the eastern provinces of the Umayyad caliphate under Mu'āwiya. According to al-Ṭabarī, Ziyād was the first to have people walk in front of him in formal processions carrying lances

${ }^{14}$ Al-Ya'qūbī, Ta'rīkh al-Ya 'qūbì, II, p. 232.

${ }^{15}$ Ibn 'Asākir, Ta'rīkh madīnat Dimashq, LVIII, p. 150.

${ }^{16}$ Al-Ṭabarī, Ta'rīkh, second series I, p. 205 (English translation: XVIII, p. 216). See also: Ibn 'Asākir, Ta'rīkh, XXXIII, p. 32.

${ }^{17}$ On the awa' $i l$ see: Noth, The Early Arabic Historical Tradition: A Source-Critical Study, pp. 104-8. See also: Donner, "The Shurta in Early Umayyad Syria," p. 248.

${ }^{18}$ Ibn 'Asākir, Ta'rīkh, LIX, pp. 143-44.

${ }^{19}$ Ibn Khallikān, Wafayāt al-a 'yān wa-anbā'abnā'al-zamān, V, p. 319. Nușayr Abū Mūsā "had been in the immediate entourage of Mu'āwiya": Lévi-Provençal, "Mūsā b. Nușayr," in $E I^{2}$. 
(hirāb) and clubs ('umud). He also established the haras as a cavalry unit (rābita) of 500 men. Ziyād appointed Shaybān of the Banū Sa'd as head of the rābita, which was stationed beside the mosque. ${ }^{20} \mathrm{Al}$-T Tabarì's report implies that the rābiț was a part of the haras. However, a report in another source describes the rābita as a unit separate from the haras, which consisted of 500 men and was under the command of Shaybān. ${ }^{21}$

Shaybān b. 'Abd al-Shams belonged to the Banū Sa'd b. Zayd Manāt b. Tamīm. He was killed by the Khawārij with seven of his sons while guarding the mosque (jāmi $\left.i^{6}\right)$ of Bașra. ${ }^{22}$ In the aforementioned accounts, he is said to have headed either the haras or the rābita, and in other accounts he is referred to as a shurta chief, which seems mistaken. ${ }^{23}$ Balj b. Nushba, who belonged to the same group of Tamīm, is said to have been the deputy (khalīfa) of Ziyād's chief of the haras. ${ }^{24}$ One would expect Balj to have replaced Shaybān and the two of them to have commanded the same body, but whether this was the haras or the rābița remains unclear.

\footnotetext{
${ }^{20} \mathrm{Al}$-Ṭabarī, Ta' rīkh, second series I, p. 79 (English translation: XVIII, p. 85). For more on the räbita as a cavalry unit see: Lane, Arabic-English Lexicon, s.v. "r.b.t." One of the functions of the rābita was to fight groups of the Khawārij, and the founder of this unit was Ziyād b. Abīhi: Athamina, "Non-Arab Regiments and Private Militias during the Umayyad Period," p. 373. In some reports Ziyād is said to have been the founder of both the haras and the 'asas (a night patrol unit): al-'Askarī, al-Awā'il, p. 204; al-Qalqashandī, Șubh ala shā fí șinā 'at al-inshā', I, p. 473. According to other reports, Abū Bakr or 'Umar b. alKhattāb established this unit. For more on the "asas see: Bearman et al., "Asas," in $E I^{2}$; Darädkeh, "al-Haras wa-1-shurța," pp. 71-72; Ebstein, "Shurța Chiefs in Bașra," p. 114.

${ }^{21}$ Al-Balādhurī, Ansā̄b al-ashrāf, IVa, p. 192. See also: Ebstein, "Shurța Chiefs in Bașra," pp. 113-14. Wa-kāna Ziyād awwal mani ttakhadha l-haras wa-ttakhadha l-thiyāba l-Ziyādiyya wa-awwal man mushiya bayna yadayhi bi-l-hirāb wa-l-a 'mida. Wa-ttakhadha Ziyād rābita 'iddatuhum khams mi'a wa-wallā amrahum Shaybān șāhib maqbarat Shaybān min Bañ̄ Sa'd. fa-kānū lā yabrahūna l-masjid (Ziyād was the first to establish the haras and to have men wear the "Ziyādī" clothes (it is not clear if this was the uniform of the haras members). He was the first in front of whom people walked with lances and clubs. Ziyād established a cavalry unit, which included 500 men, and appointed Shaybān of the Banū Sa'd, the owner of maqbarat Shaybān, in charge of them. They did not leave the mosque). The haras members do not seem to have had qualifications relating them to cavalry units. However, an account of the formal processions of the caliph Hishām might give a different impression: wa-kāna fì mawkib Hishām thamānī mi'at färis wa-(!)arba ' mi'a mina l-shurța wa-arba 'mi'a mina l-ḥaras (There were 800 horsemen in Hishām's procession: 400 from the shurta and 400 from the haras): al-Balādhurī, Ansāab, VIb, p. 27.

${ }^{22}$ Ibn Durayd, al-Ishtiqā $q$, p. 253. See also: al-Balādhurī, Ansāb, IVa, p. 149.

${ }^{23}$ Al-Balādhurī, Ansāb, XI, M. al-Firdaws al-'Aẓm (ed.), p. 483. In Futūh al-buldān he is called the shurța chief of Ziyād's son: al-Balādhurī, Futūh al-buldān, p. 504. This confusion between the haras and shurța bodies is discussed below.

${ }^{24}$ Al-Balādhurī, Ansāb, IVa, p. 178.
} 


\section{Characteristics of the Haras and the Haras Chiefs}

The following sections attempt a review of the characteristics of the haras, based on information gathered regarding the haras chiefs. The method employed is that of prosopography, ${ }^{25}$ i.e. a study of a group of individuals with common background characteristics. Questions of interest about this group include their genealogy, social origins, economic position, offices held by them, the position of their descendants, political connections, etc. The group discussed here is that of the haras chiefs of the caliphs during the first two centuries of Islam. Accounts regarding the haras typically do not elaborate on the functions of the institution itself, but rather relate to the haras chiefs. Hence, a review of the characteristics of the haras institution would be inadequate without a discussion of the men who headed it. ${ }^{26}$

There are naturally some deficiencies in the data, which should be considered. The sources offer abundant data regarding some haras chiefs, whereas information about others is lacking. Several haras chiefs appear only a few times in the sources, sometimes even without a name. There is a risk that the haras chiefs about whom the reports provide sufficient information do not represent the entire group. Nevertheless, an examination of the various haras chiefs may shed light on the characteristics of the haras institution.

The evidence used here is taken from an online database titled "The Prosopography of Early Islamic Administration." This project aims to record biographical information from the primary sources about people who played a role in administration and politics during the early Islamic period. ${ }^{27}$

${ }^{25}$ On the method of prosopography, see: Stone, "Prosopography," pp. 107-40.

${ }^{26}$ See also: Kennedy, The Armies of the Caliphs, xi: "The Islamic historians are more interested in individuals and groups of individuals rather than institutions... This in turn makes the writing of history heavily prosopographical." On the necessity of prosopography in studying Islamic history see also: Crone, Slaves on Horses, pp. 16-17.

27 The Jerusalem Prosopography Project: The Prosopography of Early Islamic Administration, at: www.micro5.mscc.huji.ac.il:81/JPP/v3. See also: Lecker, "The Prosopography of Early Islamic Administration," pp. 529-33. 


\section{Mawālī}

Most of the haras chiefs who served during the Umayyad period were mawāli (pl. of mawlā.$^{28}$ The bodyguards who were mawāli were most likely mawāl $\bar{\imath}$ in the sense of non-Arab clients, freedmen. ${ }^{29}$ One report explicitly states that 'Amr b. Muhājir, who was the haras chief of 'Umar b. 'Abd al-'Azīz (r. 99-101/717-720), was a mawlā 'atāqa (freed slave) of Asmā' bint Yazīd al-Anșariyya. ${ }^{30}$ There are accounts according to which Yazīd b. Abī Muslim, who was appointed governor of North Africa by Yazīd b. 'Abd al-Malik (r. 101-105/720-724), returned the mawāli of Mūsā b. Nușayr to slavery and used them as his haras, which indicates that they had been freed slaves. ${ }^{31}$ The fact that the haras was headed by mawāli suggests that the members of this body were mawāli as well. ${ }^{32}$

'Amr b. Muhājir was the only haras chief who was a mawlä of the Anșār. Since 'Umar b. 'Abd al-'Azīz was the governor of Medina before his appointment as caliph and had close relations with some of the Anșār ${ }^{33}$ it seems reasonable that a mawlā of theirs should have been selected as his haras chief.

${ }^{28}$ Haras chiefs who were mawālì include: Muslim Abū 'Abd Allāh, al-Mukhtār or Abū l-Mukhāriq (see p. 319), Sa ‘īd b. Zayd (Ibn 'Asākir, Ta'rīkh, XXI, p. 95), 'Adī Abū 'Ayyāsh (on whom see Appendix 1, where the haras chiefs are organized according to chronological order. The numbering used is given in parentheses), Abū l-Zu'ayzi'a (2), alRayyān b. Khālid and Khālid b. al-Rayyān (3), 'Amr b. Muhājir (4), al-Rabī' b. Ziyād (5), Ghaylān b. Abī Ma'shar (6), Qiṭrīi, Sallām, and Siqlāb (al-Ya'qūbī, Ta'rīkh, II, pp. 334, $335,346-47)$.

${ }^{29}$ On the various meanings of mawlā see: Crone, "Mawlā," in $E I^{2}$; Landau Tasseron, "Alliances in Islam," p. 25; Hasson, "Les mawali dans l'armée musulmane sous les premiers Umayyades," pp. 176-213.

${ }^{30}$ Ibn 'Asākir, Ta'rīkh, XLVI, p. 402. On 'Amr b. Muhājir see Appendix 4.

${ }^{31}$ Al-Ya'qūbī, Ta'rīkh, II, p. 313: wa-akhadha mawāliya Mūsā b. Nușayr fa-wasama aydiyahum wa-raddahum ilā l-riqq wa-stakhdama 'āmmatahum fì harasihi (he (Yazīd) took the mawālī of Mūsā b. Nușayr, branded their hands, returned them to slavery, and used them as his haras). See also: Ibn 'Idhārī, Kitāb al-bayān al-mughrib fì akhbār al-Andalus wa-l-Maghrib, I, pp. 48-49; al-Balādhurī, Futūh al-buldān, p. 324; Robinson, "NeckSealing in Early Islam," p. 422.

${ }^{32}$ See also: Kennedy, The Armies of the Caliphs, p. 32.

${ }^{33}$ Cobb, "'Umar (II) b. 'Abd al-'Azīz," in $E I^{2}$. When 'Umar b. 'Abd al-'Azīz was the governor of Medina he appointed a man from the Anșār named Abū Bakr b. Muhammad b. 'Amr b. Hazm as $q \bar{a} d \bar{l}$. During 'Umar's caliphate, Abū Bakr was the governor of Medina. Ibn 'Asākir, Ta' rīkh, LXVI, pp. 44-45. See also: Lecker, “'Amr ibn Ḥazm al-Anșārī and Qur'ān 2,256: ‘No Compulsion Is There in Religion',” pp. 60-61. 
The reason for choosing mawāli to head the haras was their unconditional loyalty to the caliph. The caliph wanted the most trustworthy men, and naturally it was his mawāl $\bar{l}$ who were closest to him, as against Arab tribesmen whose loyalty was principally to their tribes. A reference to the mawāl $\vec{\imath}$ 's loyalty and obedience can be found in a report stating that $\mathrm{Mu}$ 'āwiya wrote to Ziyād b. Abīhi complaining about his relatives. In response, Ziyād advised him to rely more on his mawāl $\bar{\imath}$ since they were more helpful, more willing to forgive, and more grateful. ${ }^{34}$

The mawāli held several offices during the Umayyad period. ${ }^{35}$ According to Ziyād b. Abīhi, it is better that the men in charge of the kharāj (tax, especially land tax) should be non-Arabs who are more proficient in these matters. ${ }^{36}$ The chamberlains (hujjāb) of the prophet and of the caliphs were reported to have been mostly mawāli as well. ${ }^{37}$ However, the chamberlains were largely mawāli of the caliph, whereas the haras chiefs were occasionally the caliph's mawāli , but not necessarily. ${ }^{38}$

\section{Qualifications of the haras chiefs}

Several haras chiefs held additional offices, such as responsibility for the khätam (seal), hijāba, and dīwān al-rasā'il (office of correspondence) ${ }^{39}$ Some held administrative positions before their appointment as haras chiefs. ${ }^{40}$ Some positions were security related, like the hijāba,

34 'Alayka bi-l-mawālì fa-innahum anșar wa-aghfar wa-ashkar: al-Balādhurī, Ansāb, IVa, p. 23; Athamina, "Non-Arab Regiments," p. 374; Kister, "The Battle of the Harra: Some Socio-Economic Aspects," p. 44. As for the loyalty of the haras chief, Ziyād b. Abīhi is also reported to have claimed that the haras chief should be an aged man, who is chaste, reliable, and free from blame: wa-yanbaghī an yakūna șăhibu l-haras musinnan 'afífan ma'mūnan lā yuț'anu 'alayhi: al-Ya'qūbī, Ta'rīkh, II, p. 235.

${ }^{35}$ See also: Husayn, "The Participation of non-Arab Elements in the Umayyad Army and Administration," p. 274.

${ }^{36} \mathrm{Al}-\mathrm{Ya}$ 'qūbī, Ta'rīkh, II, p. 234.

${ }^{37}$ Ibn Ḥabīb, Kitāb al-muhabbar, pp. 258-59.

${ }^{38}$ See also: Crone, "Mawlā," in $E I^{2}$ : "The haras, or palace-guard, of the caliphs and their governors also seems usually to have been composed of and headed by mawāli though not necessarily mawāli of the employer."

${ }^{39}$ Kennedy, The Armies of the Caliphs, p. 35; Ebstein, "Shurța Chiefs in Bașra," p. 117. Such were Abū 1-Zu'ayzi'a (2), al-Rabī' b. Ziyād (5), al-Naḍr b. 'Amr (7), Asad b. 'Abd Allāh (8), 'Uthmān b. Nahīk (9), and Abū 1-'Abbās al-Ṭūsī (10).

${ }^{40}$ For example, Abū 1-Zu'ayzi'a (2) and 'Amr b. Muhājir (4). 
while others seem strictly administrative and unconnected to any security job. It may be inferred that the qualifications required of a haras chief were not merely military skills, physical strength, and loyalty to the caliph, but also administrative capabilities. ${ }^{41}$

The loyalty of the haras chiefs to the caliph and their intimate relationship with him enabled them to secure various administrative positions for themselves, which likewise demanded loyalty and a close relation with the caliph. Perhaps their non-Arab background and the administrative traditions to which they were accustomed enabled them to occupy these positions.

Unlike the haras chiefs who served the Umayyads, several haras chiefs were promoted to the rank of governors during the early Abbasid period. ${ }^{42}$ Moreover, the haras chiefs during the early Abbasid period were occasionally in charge of the army and sometimes of the khazá 'in (state treasury). ${ }^{43}$ The appointment of haras chiefs during the early Abbasid period as governors also suggests that the haras chiefs may have had skills that were not necessarily related to matters of security.

Several times a relative of the haras chief succeeded him as head of the haras ${ }^{44}$ It would seem that a person related to the haras chief had quite a good chance of succeeding him. According to some reports, certain haras chiefs were hadith transmitters ${ }^{45}$ but their knowledge of hadith was not ostensibly related to their security job.

${ }^{41}$ See also Wadād al-Qāḍ̂̄'s reconstruction of the biography of Ma'bad b. Khālid alJadalī, whose first job was as a harasī under the governor of Kūfa. She concludes that the guards also had qualifications that were unrelated to physical strength: "Ma"bad's story shows that even a guard - certainly a chief guard - may be asked to undertake missions that require extensive knowledge of the territory in which he serves, including knowledge of its political and tribal landscape, and have the courage to carry out difficult, delicate, and possibly unsavory assignments:" al-Qāḍ̄i, "Security Positions," p. 281.

${ }^{42}$ For example: Abū l-'Abbās al-Ṭūsī (10), Shabīb b. Humayd b. Qaḥtaba (12), 'Alī b. 'Īsā b. Māhān (Sourdel, "Ibn Māhān, 'Alī b. 'Īsā b. Māhān," in $E I^{2}$; Crone, Slaves on Horses, p. 178), and Harthama b. A 'yan (Pellat, "Harthama b. A'yan," in EI'; Crone, Slaves on Horses, p. 177).

${ }^{43}$ Crone, Slaves on Horses, p. 248.

${ }^{44}$ See Appendix 1, 3, 6, 8, 9, and 10.

${ }^{45}$ Like 'Amr b. Muhājir (4) and Abū l-Zu'ayzi'a (2): Ibn 'Asākir, Ta'rīkh, XLVI, p. 402, XX, p. 88. 
Weapons used by the haras

The reports concerning the establishment of the haras mention the weapons hirāb and 'umud. 'Umud or a 'mida (pl. of 'amūd) were clubs or maces, possibly made of iron, ${ }^{46}$ and hirāb (pl. of harba) were short spears or lances that were considered a symbol of authority. The Negus, or the ruler of Ethiopia, allegedly granted the prophet a lance ('anaza, syn. of harba), and people used to walk in front of him with it. After the prophet's death, the caliphs are said to have inherited this lance and to have had people walk in front of them carrying it. Reportedly, the prophet fought Ubayy b. Khalaf with the lance he received from the Negus during the battle of Uhud. ${ }^{47}$ It seems however that the hirāb and 'umud were not the weapons borne by the members of the haras during formal processions; rather, the shurț members used to carry them. ${ }^{48}$

Concerning the weapons of the haras chiefs, the most commonly used was the sword. ${ }^{49}$ Receiving a sword occasionally symbolized appointment to this position..$^{50}$ Sometimes the haras chiefs used chains

\footnotetext{
${ }^{46}$ Crone, "The Significance of Wooden Weapons in Al-Mukhtār's Revolt and the 'Abbasid Revolution," p. 177; Lane, Arabic-English Lexicon, s.v. “".m.d”; Ebstein, "Shurța Chiefs in Bașra," p. 109.

${ }^{47}$ Ibn 'Asākir, Ta'rīkh, IV, pp. 218-19; Darādkeh, "al-Ḥaras wa-1-shurța," pp. 70-71; for more on the harba as a symbol of authority and the custom of walking in front of the caliph with the harba see: Sourdel, "Khalīfa," in EI' Kennedy, The Armies of the Caliphs, p. 176; Ebstein, "Shurța Chiefs in Bașra," p. 109.

${ }^{48}$ Kennedy, The Armies of the Caliphs, pp. 13, 176; Ebstein, "Shurț Chiefs in Bașra," p. 109; Crone, "The Significance of Wooden Weapons," p. 177. Darādkeh and Morony remark that the haras members walked in front of the caliph with 'umud and hirāb: Darādkeh, "al-Haras wa-l-shurta," p. 89; Morony, Iraq, p. 93. In some accounts the haras members used the harba as a standard weapon, and in others the haras members in the mosque held 'umud: Ibn 'Asākir, Ta'rīkh, XI, p. 431; al-Dīnawarī, al-Akhbār al-țiwāl, p. 199.

${ }^{49}$ Swords are explicitly mentioned in the reports concerning Abū 1-Zu'ayzi'a (2), Khālid b. al-Rayyān (3), and 'Uthmān b. Nahīk (8). The sword was a significant and symbolic weapon in Islam. The name sayf (sword) was used as an honorific title already at the time of the prophet. Sometimes the sword itself was given a name, like Dhū l-Faqār "Alī's sword, which was allegedly given to him by the prophet: Elgood, "Arms and armour," in $E I^{3}$. There are several words in Arabic indicating different types of swords, as well as terms signifying the different parts of the sword, which also emphasizes its cultural importance. The significance of the sword is also illustrated in poetry, and several verses praise the virtues of this weapon. For more on swords in Islam see: Hoyland and Gilmour, Medieval Islamic Swords and Swordmaking: Kindi's treatise "On swords and their kinds".

${ }^{50}$ Like the appointment of 'Amr b. Muhājir (4).
} 
(silsila, pl. salāsil) as an instrument of torture. ${ }^{51}$ Other reports state that the haras members used whips (sawt, pl. siyat t). ${ }^{52}$

\section{Confusion between the terms haras and shurța}

Several haras chiefs are referred to in the sources as shurta chiefs,,$^{53}$ and it seems that there is some confusion between the two terms. ${ }^{54}$ What is more, the term shurta (pl. shurat) has occasionally been translated in modern studies as bodyguard. ${ }^{55}$ The haras and the shurta were related, since both bodies dealt with security, but their functions were distinct. The shurta was in charge of maintaining public order and security, while the haras was responsible for the personal safety of the caliph. The distinction can be seen quite clearly in the origin of the men who headed the haras and the shurta: the Umayyad haras chiefs were mainly mawāli , whereas most shurța chiefs were Arab tribesmen. ${ }^{56}$

\footnotetext{
${ }^{51}$ As mentioned regarding Abū l-Zu'ayzi‘a (2) and Sa‘īd b. Ghaylān (6).

${ }^{52}$ Ibn al-'Adīm, Bughyat al-țalab fì ta' rīkh Halab, V, p. 2322; al-Șan'ānī, al-Muṣannaf, IX, p. 331.

${ }^{53}$ See reports on Abū l-Zu'ayzi'a (2), 'Amr b. Muhājir (4), Sa 'īd b. Ghaylān (6), and alNaḍr b. 'Amr (7). Likewise, verses composed by 'Umayr b. al-Hubāb (on whom see: Crone, Slaves on Horses, pp. 107-8) describe how he managed to escape from the shurta of al-Rayyān b. Khālid, who was in fact responsible for the haras (3). 'Ațâ’ b. Abī l-Sā'ib, the haras chief of Umayya b. 'Abd Allāh, who was the governor of Khurāsān during the caliphate of 'Abd al-Malik, is referred to in the same report once as Umayya's haras chief and once as his shurta chief: al-Ṭabarī, Ta'rīkh, second series II, pp. 1028-30 (English translation: XXII, pp. 17274). Kaysān Abū 'Amra, the haras chief of al-Mukhtār b. Abī 'Ubayd (d. 67/687), is referred to in another source as his shurța chief: al-Jumahī, Țabaqāt fuhūl al-shu' 'arā', II, p. 632.

${ }^{54}$ As mentioned in the Encyclopaedia of Islam: "The șăhib al-shurta appears often in the early centuries as the head of the ruler's personal bodyguard, a function whose title and role is confused with that of the haras": Nielsen, "Shurta," in $E I^{2}$. On the confusion between the two institutions see also: Rashid, The Role of the Shurta, p. 153.

${ }^{55}$ Dodge translates the title Kitäb shurat al-khulafă' from the Fihrist of Ibn al-Nadīm as: "Bodyguards of the Caliphs." The title Kitāb 'ummal al-shurat li-umarā' al-'Irāq is translated as: "Officers of the Bodyguards of the Governors of al-'Irāq": Ibn al-Nadīm, The Fihrist of al-Nadim: A Tenth Century Survey of Muslim Culture, I, p. 218; Ibn alNadīm, al-Fihrist li-Ibn al-Nadìm, p. 146. See also: Elad, "Community of Believers of 'Holy Men' and 'Saints' or Community of Muslims? The Rise and Development of Early Muslim Historiography," pp. 297-98. Wellhausen explains shurta as "einer Art Gensdarmerie." See also the English translation: "a kind of body-guard": Wellhausen, Das Arabische Reich und sein Sturz, p. 80; Wellhausen, The Arab Kingdom and its Fall, p. 127. See also: Donner, "The Shurta in Early Umayyad Syria," p. 257.

${ }^{56}$ Donner, "The Shurta in Early Umayyad Syria," p. 258; Kennedy, The Armies of the Caliphs, p. 13; Ebstein, "Shurța Chiefs in Bașra," p. 117.
} 
Some reports note that a certain person functioned as a haras chief, while others say that the same person was a hajjib (chamberlain) of the caliph, which can also be explained as a result of confusion between the two terms. ${ }^{57}$ It is perhaps possible that there is no contradiction between the reports, and that these people held the two positions simultaneously.

\section{Characteristics of the haras}

Since the time of Mu'āwiya b. Abī Sufyān, each caliph had a haras, led by a haras chief, who escorted him. There was only one haras chief at a time. When the sources remark that a certain caliph had more than one, it is because different people functioned at different times. It seems that the caliph himself appointed and dismissed his haras chief, which is another indication of their close relations. Occasionally a haras chief functioned under more than one caliph. ${ }^{58}$ Thus, several times a new caliph did not choose a new haras chief, but rather employed the one already in command. The continuity of the haras is also evident from the fact that it was a body that functioned during both the Umayyad and Abbasid periods.

Regarding the numbers provided by the sources, ${ }^{59}$ the report concerning the establishment of the haras by Ziyād notes that the haras comprised 500 men. However, as previously mentioned, this report is ambiguous, because it is not clear whether this unit was the haras or the rābita. The haras of 'Umar b. 'Abd al-'Azīz consisted of 300 men, ${ }^{60}$ and the formal procession of Hishām b. 'Abd al-Malik included 400 haras members. ${ }^{61}$ A report regarding al-Mahdī remarks that he took 500 men from the Anșār (i.e. descendants of the Anșār) and made them his haras. ${ }^{62}$ The salary of the haras chief is not dis-

${ }^{57}$ See for example reports concerning Ahmad b. Hishām (11), Siqlāb and Qiṭrī (alYa 'qūbī, Ta' rīkh, II, pp. 334, 346-47; Ibn Ḥabīb, Kitāb al-muhabbar, p. 258).

${ }^{58}$ Such as Khālid b. al-Rayyān (3), who served under three caliphs, and Abū 1-'Abbās al-Ṭūsī (10) who served under two.

${ }^{59}$ Regarding typological numbers and numbers in general given in the Muslim sources see: Kennedy, The Armies of the Caliphs, xii-xiii, pp. 19-21; Noth, The Early Arabic Historical Tradition, pp. 198-200.

${ }^{60}$ Ibn 'Asākir, Ta' rīkh, XLV, p. 220.

${ }^{61}$ Al-Balādhurī, Ansāab, VIb, p. 27.

${ }^{62}$ Al-Ṭabarī, Ta'rīkh, third series I, p. 484 (English translation: XXIX, p. 195). 
cussed in detail in the sources, but some reports refer briefly to this issue. ${ }^{63}$

Numerous reports discuss the haras chiefs of governors as opposed to caliphs. ${ }^{64}$ There are also reports of qudiat (pl. of $q \bar{a} d \bar{l} \bar{l}$ ) who had a haras.$^{65}$ Not all governors, nor all of the qudat , are said in the sources to have employed a haras, but it may be assumed that nearly all governors and possibly other officials as well had a haras guarding them.

\section{The haras in the mosque}

Reports on the establishment of the haras mention that its members were stationed inside the mosque in order to protect the caliph while praying. Other reports describe the actions of the haras members inside the mosque, such as expelling people from it for various reasons. ${ }^{66} \mathrm{Per}-$ haps some of the haras members were charged with keeping the mosque safe and protecting the caliph when he was there, but it is dif-

${ }^{63}$ 'Umar b. 'Abd al-'Azīz gave 'Amr b. Muhājir a monthly salary of ten or twenty dīnārs (4). In a report that describes the marriage of 'Abd al-'Azīz b. al-Walīd (the son of the Caliph al-Walīd b. 'Abd al-Malik) and Umm Hakīm, 'Abd al-Malik, who was 'Abd al-'Azīz's grandfather, ordered to give the haras members ten dīnārs each: Abū l-Faraj alIșfahān̄, Kitāb al-aghān̄̄, XVI, p. 298. The salary of the haras chief of Hārūn al-Rashīd was 300,000 dirhams per year: Ibn Faḍl Allāh al-'Umarī, Masālik al-abṣār fì mamālik alamșār, IX, p. 190.

${ }^{64}$ For example: Janāb b. Marthad was the haras chief of 'Abd al-'Azīz b. Marwān, the governor of Egypt (al-Maqrī̄īi, al-Muqaffà l-kabīr, III, p. 72); Yazīd b. Abī Ziyād headed the haras of Muțarrif b. al-Mughīra (al-Ṭabarī, Ta'rīkh, second series II, p. 983); 'Ațâ' b. Abī l-Sā'ib al-Laythī was in command of the haras of Umayya b. 'Abd Allāh, the governor of Khurāsān (al-Ṭabarī, Ta' rīkh, second series II, pp. 1028-30); 'Abd Allāh b. Dīnār was the haras chief of 'Adī b. Arțā (al-Ṭabarī, Ta'rīkh, second series II, p. 1384); Dāwūd al-Barbarī led the haras of Khālid al-Qasrī (al-Ṭabarī, Ta'rìkh , second series III, p. 1650); Abū Muslim's haras chief was named Abū Isḥāq Khālid b. 'Uthmān (al-Ṭabarī, Ta'rīkh, third series I, p. 116).

${ }^{65}$ See for example: Ibn 'Asākir, Ta'rīkh, XX, p. 216; Ibn Sa'd, al-Ṭabaqāt al-kubrā: al-qism al-mutammim li-tābi 'ī ahl al-Madīna wa-man ba 'dahum, p. 125; Wakī', Akhbār al-qud̄at, I, pp. 145, 213-14. Additionally, some rebels possessed a haras. Al-Mukhtār b. Abī 'Ubayd's haras was led by a mawlā of 'Urayna named Kaysān Abū 'Amra (see also note 53): Hawting, "al-Mukhtār b. Abī 'Ubayd," in $E I^{2}$.

${ }^{66}$ See for example: al-Balādhurī, Ansāb, VII, M. al-Firdaws al-'Aẓm (ed.), p. 522; Ibn al-Athīr, al-Kāmil fì l-ta'rīkh, IV, p. 262; al-Kindī, Wulāt Miṣr, p. 83; al-Samhūdī, Wafāa' al-wafā bi-akhbār dār al-Muștafāa, II, p. 284-285; Ibn Abī Shayba, al-Mușannaf li-Ibn Abì Shayba, XII, p. 574. 
ficult to ascertain whether they indeed belonged to the body under the command of the haras chief of the caliph, or were a separate unit responsible for maintaining order in the mosque.

\section{Functions of the haras}

The main function of the haras was to guard the caliph and to prevent his exposure to any kind of danger. Even when the caliph was in a private meeting, his haras chief was with him to guard him, armed with a sword. An anecdote about 'Umar b. 'Abd al-'Azīz shows how the haras protected the caliph and escorted him: when 'Umar became caliph, he walked at night with a haras member (harasī) to the mosque. 'Umar entered the mosque, and because of the darkness he bumped into a sleeping man. The man lifted his head and said: "Are you crazy?" The haras member intended to harm him, but 'Umar told him that the man was simply asking him a question and that he had answered by telling him that he was not crazy. ${ }^{67}$ Although all this might not have occurred at all, the background details are trustworthy: the caliph was escorted by his haras at all times.

In addition to protecting the caliph, the haras carried out executions at his orders. ${ }^{68}$ Several reports demonstrate how the haras members dealt with opponents of the caliph. For instance, the haras had a central role during the $b a y$ ' $a$ (oath of allegiance) to Yazīd b. Mu'āwiya (r. 60-64/680-683) ${ }^{69}$ Reportedly, Mu'āwiya threatened the men who refused to pledge the bay ' $a$ to Yazid, and he forced them to accept his son's appointment as his heir apparent. Mu'āwiya summoned his haras chief and ordered him to place two haras members next to each of the men present during his speech. Had any of them said anything

\footnotetext{
${ }^{67}$ Ibn 'Asākir, Ta'rīkh, XLV, p. 206. Another anecdote about 'Umar b. 'Abd al-'Azīz also says that the haras members accompanied the caliph to the mosque: Ibn 'Abd Rabbihi, al-'Iqd al-farìd, II, p. 269.

${ }^{68}$ See also: Darādkeh, "al-Ḥaras wa-1-shurța," p. 81. Haras chiefs ordered to perform executions include Abū l-Zu'ayzi'a (2), 'Uthmān b. Nahīk (9), 'Abd Allāh b. Abī l-'Abbās al-Ṭūs̄i (10) and Ahmad b. Hishām (11). Several reports describe how al-Hajjāj b. Yūsuf al-Thaqaî̀ (born 4i/661) ordered his haras to perform executions: Morony, Iraq, p. 93; al-Balādhurī, Ansāb, VI, p. 488; Ibn Khallikān, Wafayāt, II, p. 38; Ibn 'Asākir, Ta'rīkh, LXXIV, p. 233.

${ }^{69}$ On the bay ' $a$ to Yazīd see: Marsham, Rituals of Islamic Monarchy: Accession and Succession in the First Muslim Empire, pp. 90-92.
} 


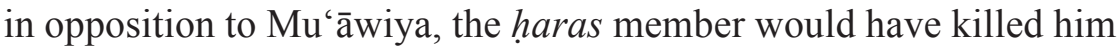
with his sword. ${ }^{70}$ In another report, Yazīd b. Mu'āwiya sent some of his haras members to 'Abd Allāh b. al-Zubayr to ascertain that the latter was obedient to him. The haras members were supposed to either receive 'Abd Allāh b. al-Zubayr's bay ' , or bring him in chains to the caliph. ${ }^{71}$

Apart from these main functions of the haras, there were others, such as prison supervision. ${ }^{72}$ It is possible that the latter was under the control of the haras chiefs, but there is not enough in the sources to determine whether this was a permanent role of the haras or only the responsibility of several specific haras chiefs. The sources also discuss various tasks assigned to the haras chiefs and the haras members, which were not necessarily related to the personal security of the ruler, ${ }^{73}$ such as performing duties related to intelligence, ${ }^{74}$ or deporting various people on the ruler's order. ${ }^{75}$

\section{Summary}

Since the time of Mu'āwiya b. Abī Sufyān, every caliph was guarded by his haras at all times. Not only were caliphs protected by bodyguards, but also governors and several other officials, which is an indication of the importance of this body. Scholars have remarked that nearly all the haras chiefs of the Umayyad caliphs were mawāli, and the confusion between the haras and the shurța has been pointed out

${ }^{70}$ Ibn al-Athīr, al-Kāmil, III, pp. 355-56.

${ }^{71}$ Al-Dīnawarī, al-Akhbār al-tîwāl, p. 241.

${ }^{72}$ See reports concerning al-Rayyān b. Khālid (3), Sa ‘̄id b. Ghaylān (6), and Aḥmad b. Hishām (11). In addition Janāb b. Marthad (see note 64) and his men struck and jailed whoever behaved in a rude manner towards 'Abd al-'Azìz: fa-kāna l-rajul idhà aghlaẓa li-'Abd al-'Azīz wa-kharaja tanāwalahu Janāb wa-man ma'ahu fa-darabūhu wahabasūhu: al-Kindī, Wulāt Miṣr, p. 71.

${ }^{73} \mathrm{~A}$ report about $\mathrm{Mu}$ 'āwiya mentions that before his death he summoned al-Ḍhhāāk b. Qays, his shurta chief, and Muslim b. 'Uqba, his haras chief, and asked them both to give Yazīd his will: al-Dīnawarī, al-Akhbār al-țiwāl, pp. 208-9; Darādkeh, "al-Haras wa1-shurța," p. 85.

${ }^{74} \mathrm{Abu}$ Muslim sent his haras chief Abū Ishāq to al-Manșūr to check al-Manșūr's opinions before he went to meet him: al-Ṭabarī, Ta' rīkh, third series I, p. 107 (English translation: XXVIII, p. 30).

${ }^{75}$ Al-Mughīra b. Shu'ba (governor 41-50/661-670) ordered Ma'bad, a member of his haras, to deport Ziyād b. Ab̄̄hi from Kūfa: al-Qāẹ̄i, "Security Positions," pp. 265-66. 
as well. Some studies have mentioned that the haras chiefs had responsibilities in addition to protecting the caliph's life, such as responsibility for the official seal. It may be supposed that their non-Arab background and administrative skills enabled them to secure such positions. During the early Abbasid period, some haras chiefs were promoted to the office of governors, perhaps implying that the qualifications for the haras position were not merely security related.

Besides the primary duty of protecting the caliphs, the haras chiefs also performed executions and were active in suppressing political opposition. Naturally, the haras chiefs had close relations with the caliph. According to some reports it was the caliph himself who appointed or dismissed his haras chief; on several occasions a relative of a haras chief succeeded him in the position. A prosopographical study of the haras chiefs shows that they had much in common, and this fact contributes to our knowledge of the haras, a significant institution during early Islam.

\section{Appendix: The Haras Chiefs of the Caliphs in Chronological Order}

1. 'Adī Abū 'Ayyāsh al-Himyarī and his son Ibn Abī 'Ayyāsh alAlhānī: 'Adī Abū 'Ayyāsh, a mawlā of Himyar, was the haras chief of the Caliph 'Abd al-Malik b. Marwān (r. 65-86/685-705). ${ }^{76}$ His son, Ibn Abī 'Ayyāsh al-Alhān̄̄, was the haras chief of 'Umar b. 'Abd al-'Azīz (r. 99-101/717-720). ${ }^{77}$

2. Sālim Abū 1-Zu'ayzi'a al-Barbarī: Abū 1-Zu'ayzi'a was a mawlā of the Caliph 'Abd al-Malik b. Marwān and his haras chief after Abū 'Ayyāsh al-Himyarī. ${ }^{78} \mathrm{He}$ was also in charge of 'Abd al-Malik's dīwān al-rasā' $i l,{ }^{79}$ and prior to his appointment as haras chief, according to one version, he had been a kātib (secretary) of Marwān b. al-Hakam

${ }^{76}$ Ibn 'Asākir, Ta' rìkh, XL, p. 159.

${ }^{77}$ Ibn 'Asākir, Ta'rīkh, LXVIII, p. 40; Ibn al-'Adīm, Bughyat al-talab, X, p. 4705. In one source, 'Adī Abū 'Ayyāsh is named Abū 'Ayyāsh al-Kahānī (al-Ya'qūbī, Ta'rīkh, II, p. 280), but the name al-Kahān̄i is a miswriting of al-Alhān̄i. Abū 'Ayyāsh al-Kahānī is thus actually 'Adī Abū 'Ayyāsh al-Alhānī, the father of Ibn Abī 'Ayyāsh al-Alhānī.

${ }^{78}$ Al-Ya'qūbī, Ta'rīkh, II, p. 280.

${ }^{79}$ Al-Jahshiyārī, Kitāăb al-wuzarā 'wa-l-kuttāb, p. 35; al-Ṭabarī, Ta'rīkh, second series II, p. 838 (English translation: XXI, p. 215). 
(r. 64-65/684-685). ${ }^{80} \mathrm{Abū} \mathrm{1-Zu'ayzi'a} \mathrm{executed} \mathrm{'Amr} \mathrm{b.} \mathrm{Sa'īd} \mathrm{al-Ash-}$ daq using either a chain (silsila) or a sword. ${ }^{81}$ In one account regarding this execution, he is referred to as 'Abd al-Malik's shurta chief..$^{82}$

3. Al-Rayyān b. Khālid and his son Khālid b. al-Rayyān: AlRayyān b. Khālid was a mawlā and a haras chief of the Caliph 'Abd al-Malik b. Marwān. He was responsible for supervising the prisoner 'Umayr b. al-Hubāb al-Sulamī, who eventually managed to escape. ${ }^{83}$ Khālid b. al-Rayyān, a mawlā of Banū Muhārib, ${ }^{84}$ succeeded his father as 'Abd al-Malik's haras chief. Khālid also headed the haras of alWalīd b. 'Abd al-Malik (r. 86-96/705-715) and Sulaymān b. 'Abd alMalik (r. 96-99/715-717). When 'Umar b. 'Abd al-'Azīz became caliph, he dismissed Khālid and ordered him to lay down his sword, because the latter is reported to have said that had he received an order to kill him he would have done so. Khālid's successor, 'Amr b. Muhājir, allegedly took Khālid's sword when he was appointed 'Umar's haras chief. ${ }^{85}$

4. 'Amr b. Muhājir: 'Amr b. Muhājir b. Dīnār b. Abī Muslim, a mawlā of Asmā' bint Yazīd al-Anșāriyya, ${ }^{86}$ was appointed haras chief of the Caliph 'Umar b. 'Abd al-'Azīz following the dismissal of Khālid b. al-Rayyān. ${ }^{87}$ Some reports state that he was in charge

${ }^{80}$ Ibn 'Asākir, Ta'rīkh, XX, p. 88; al-Jahshiyārī, Kitāb al-wuzarā', p. 33.

${ }^{81}$ Al-Balādhurī, Ansāb, IVb, p. 141. 'Amr b. Sa'īid al-Ashdaq was an Umayyad governor who stirred up a revolt in Damascus asserting his right to the caliphate. The Caliph 'Abd al-Malik, who was his cousin, had him killed: Zetterstéen, “"Amr b. Sa'īd b. al-'Āṣ b. Umayya al-Umawī, known as al-Ashdak," in $E I^{2}$.

${ }^{82}$ Al-Balādhurī, Ansā̄b, IVb, p. 145.

${ }^{83}$ Al-Balādhurī, Ansāab, V, p. 314. For more on al-Rayyān b. Khālid see: Ibn 'Asākir, Ta'rīkh, XVIII, p. 274.

${ }^{84}$ His father, al-Rayyān b. Khālid, is also said in one report to have been a mawlā of Banū Muḥārib: Khalīfa b. Khayyāt, Ta'rīkh Khalīfa b. Khayyāt, p. 299.

${ }^{85} \mathrm{Ibn}$ 'Asākir, Ta'rīkh, XVI, pp. 28-29; Ibn al-'Adīm, Bughyat al-țalab, VII, pp. 3028 29. According to a different version, the Caliph dismissed Khālid b. al-Rayyān since he saw him wearing one of his ('Umar's) robes (jubba): Ibn 'Asākir, Ta'rīkh, XLVI, p. 405. Similar to Khâlid's dismissal was the dismissal of al-Ja'd b. Qays from the shurta, after Ziyād ordered him to throw down his harba: Darādkeh, "al-Haras wa-l-shurța," p. 99.

${ }^{86}$ Asmā' bint Yazīd b. al-Sakan was a member of the Banū 'Abd al-Ashhal, a clan of the Aws tribe: Ibn 'Asākir, Ta'rīkh, LXIX, p. 31.

${ }^{87} \mathrm{Ibn}$ 'Asākir, Ta'rīkh, XVI, pp. 28-29. According to other reports he was appointed after the dismissal of Ibn Abī 'Ayyāsh: Ibn 'Asākir, Ta' rīkh, LXVIII, p. 40. Another report has it that Abū 1-'Abbās al-Hilālī headed the haras of 'Umar: Ibn 'Abd Rabbihi, al-'Iqd, V, p. 179. 
of 'Umar's shurta. ${ }^{88}$ During the caliphate of al-Walīd b. 'Abd alMalik, 'Amr was in charge of the state treasury (bayt al-māl). ${ }^{89} \mathrm{Re}-$ portedly, one of the reasons for 'Amr b. Muhājir's appointment as haras chief was his Anșārī origin. His monthly salary was ten or twenty dīnārs. ${ }^{90}$

5. Al-Rabī' b. Ziyād b. Sābūr: Al-Rabī` b. Ziyād b. Sābūr, a mawlā of al-Harīsh (a Qays 'Aylān tribe), was responsible for the dīwān alrasā' $i l$, the khātam, the hijāba and the haras of the Caliph Hishām b. 'Abd al-Malik (r. 105-125/724-743). He was appointed haras chief after Hishām dismissed his mawlā Nușayr. ${ }^{91}$

6. Ghaylān b. Abī Ma'shar: Ghaylān b. Abī Ma'shar, a mawlā of alWalìd b. 'Abd al-Malik, is said in one report to have been the haras chief of both Yazīd b. 'Abd al-Malik (r. 101-105/720-724) and al-Walīd b. Yazid (r. 125-126/743-744). ${ }^{92}$ However, it seems more likely that the haras of these two caliphs was headed by two different men: Ghaylān Abu Sa'īd the haras chief of Yazīd, and his son, Sa'īd b. Ghaylān, the haras chief of al-Walīd. ${ }^{93}$ Al-Walīd ordered Sa ${ }^{\prime} \bar{i} d \mathrm{~b}$. Ghaylān to torture the former governor Khālid b. 'Abd Allāh al-Qasrī (d. 126/743-744) in

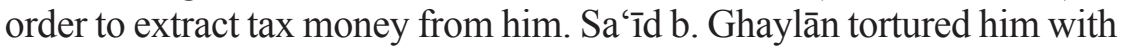
chains (salāsil) and eventually imprisoned him on the order of al-Walīd. ${ }^{94}$ p. 252 .

${ }^{88}$ Ibn 'Asākir, Ta' rīkh, XLVI, 402; al-Mizzī, Tahdhīb al-kamāl fì asmā' al-rijāl, XXII,

${ }^{89}$ Ibn 'Asākir, Ta'rīkh, II, p. 269.

${ }^{90}$ Ibn 'Asākir, Ta' rīkh, XLVI, p. 405.

${ }^{91}$ Ibn al-'Adīm, Bughyat al-țalab, VIII, p. 3590; al-Ṭabarī, Ta' rīkh, second series III, p. 1649 (English translation: XXV, p. 179); al-Balādhurī, Ansāb, VIb, p. 4 (where Nușayr is named Naṣr); Ibn 'Asākir, Ta'rīkh, LXII, p. 108 (where he is named Naḍīr. These two names are only differentiated by the diacritics). See also: Khalīfa b. Khayyāt, Ta'rīkh, p. 362 (where he is referred to once as al-Rabīi ${ }^{`} \mathrm{~b}$. Shābūr, and once as al-Rabī' b. Ziyād).

${ }^{92}$ Ibn 'Asākir, Ta'rīkh, XLVIII, p. 213. Two different versions of his name are given in this account: Ghaylān b. Abī Ma'shar and Ghaylān Khatan Ab̄̄ Ma'shar. The version with "ibn" instead of Khatan seems preferable. In another source, he is named Ghaylān Khatan Abī Ma'n (Khalīfa b. Khayyāt, Ta'rīkh, p. 262), but Ma'n could be a miswriting of Ma'shar. According to another version, Abū Mālik al-Saksakī was Yazīd's haras chief: Ibn 'Asākir, Ta'rīkh, LXVII, p. 199.

${ }^{93} \mathrm{Sa}$ ‘'̄id b. Ghaylān: al-Dīnawarī, al-Akhbār al-țiwāl, p. 319. He is referred to in this source as his shurța chief. Ghaylān Abū Sa‘̄id: Ibn 'Abd Rabbihi, al- 'Iqd, 1987, V, p. 187.

${ }^{94}$ Al-Ṭabarī, Ta'rīkh, second series III, p. 1821 (English translation: XXVI, p. 176); al-Dīnawar̄i, al-Akhbār al-țiwāl, p. 319. On Khālid b. 'Abd Allāh al-Qasrī see: Hawting, "Khālid b. 'Abd Allāh al-Kasrī," in $E I^{2}$. In al-Ṭabarī's report al-Walīd's ḥaras chief is referred to simply as Ghaylān, but al-Dīnawarī, describing the same event, names him Sa'īd b. Ghaylān. 
7. Al-Naḍr b. 'Amr al-Muqrā'ī 1-Himyarī: Al-Naḍr b. 'Amr was responsible for the kharāj (tax, especially land tax), jund (soldier enlistment), and al-khātam al-șagìr (lesser seal) together with the haras of Yazīd b. al-Walīd (r. 126/744). ${ }^{95}$

8. Asad b. 'Abd Allāh al-Khuzā'î: Asad (sometimes called Asīd) b. 'Abd Allāh al-Khuzā'ī was the haras chief of the first Abbasid Caliph, Abū 1-'Abbās al-Saffāh (r. 132-136/749-754). He was also in charge of the khātam. ${ }^{96} \mathrm{Al}-\mathrm{Ya}$ 'qūbī remarks that Asad b. 'Abd Allāh's son, Abū Bakr b. Asad b. 'Abd Allāh al-Khuzā' '⿳亠丷, , was the haras chief of Abū 1-'Abbās al-Saffāh. ${ }^{97}$ Perhaps both Asad b. 'Abd Allāh and his son who succeeded him headed Abū 1-'Abbās's haras.

9. 'Uthmān b. Nahīk: 'Uthmān b. Nahīk was appointed by the Caliph al-Manșūr (r. 136-158/754-775) to head his haras. He was also responsible for the khatam. ${ }^{98}$ Prior to his appointment as haras chief, 'Uthmān b. Nahīk took part in the killing of Yazīd b. 'Umar b. Hubayra during the siege of Wāsiț. ${ }^{99}$ When he headed the haras of al-Manșūr, his haras had an important role in the assassination of Abu Muslim, the leader of the revolutionary Abbasid movement in Khurāsān. ${ }^{100}$ 'Uthmān b. Nahīk was killed in the year 141/758, and after his death alManșūr appointed his brother, 'Īsā b. Nahīk, as haras chief. Following 'İsā's death, al-Manșūr appointed Abū 1-'Abbās al-Ṭ̂ūī to head the haras. ${ }^{101}$

${ }^{95} \mathrm{Ibn}$ 'Asākir, Ta'rīkh, LXII, pp. 77-78 (where according to one report he is said to have headed Yazīd's shurța as well); Khalīfa b. Khayyāṭ, Ta'rīkh, p. 371; al-Jahshiyārī, Kitāb al-wuzarā', p. 69; al-Ṭabarī, Ta'rīkh, second series II, p. 839 (English translation: XXI, p. 217); Crone, Slaves on Horses, p. 148.

${ }_{96}$ Khalīfa b. Khayyāt, Ta'rīkh, p. 415; see also: al-'Askarī, al-Awā'il, p. 179.

${ }^{97}$ Al-Ya'qūbī, Ta'rīkh, II, p. 361. For more on Asad b. 'Abd Allāh al-Khuzā'ī see: Crone, Slaves on Horses, pp. 175-76.

${ }^{98}$ Khalīfa b. Khayyāt, Ta'rīkh, p. 436; al-Ṭabarī, Ta'rīkh, third series I, p. 65 (English translation: XXVII, p. 188).

${ }^{99}$ Al-Balādhurī, Ansāb, III, p. 146. On Yazīd b. 'Umar b. Hubayra's death see also: Wellhausen, The Arab Kingdom, pp. 550-51; Crone, Slaves on Horses, p. 107. One account regarding this event notes that when Abū Ja'far al-Manșūr gave 'Uthmān the order to kill Yazīd, he said that a man of Arab origin should perform the execution: al-Balādhurī, Ansāb, III, p. 153 .

${ }^{100}$ On Abū Muslim see: Moscati, "Abū Muslim," in $E I^{2}$. On his assassination see: alBalādhurī, Ansāb, III, pp. 205-6.

${ }^{101}$ Ibn al-Athīr, al-Kāmil, V, pp. 129-30; al-Balādhurī, Ansāb, III, p. 236; al-Ṭabarī, Ta' rìkh, third series I, p. 131 (English translation: XXVIII, pp. 64-65). For more on 'Uthmān b. Nahīk see: Crone, Slaves on Horses, p. 189. 
10. Abū l-'Abbās al-Faḍl b. Sulaymān al-Ṭūsī and his son 'Abd Allāh b. Abī 1-'Abbās al-Ṭūsī: Abū l-'Abbās al-Ṭ̂̄sī was responsible for both the haras and the khātam of al-Manșūr. ${ }^{12}$ Abu 1-'Abbās was the haras chief of al-Mahdī (r. 158-169/775-785) as well, and during the year $165 / 781$ or $166 / 782$ al-Mahdi appointed him governor of Khurāsān. ${ }^{103}$ 'Abd Allāh b. Abī 1-'Abbās al-Ṭūsī, his son, succeeded his father as haras chief of al-Mahdi, and was ordered by the Caliph to execute 'Abd Allāh b. Abī 'Ubayd Allāh, who was accused of heresy. ${ }^{104}$

11. Ahmmad b. Hishām: Aḥmad b. Hishām was the haras chief of the Caliph al-Ma'mūn (r. 197-218/813-833). Al-Ma'mūn ordered Ahmad

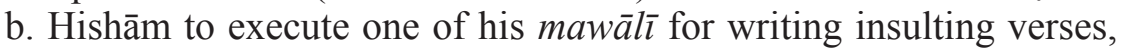
but eventually he was pardoned. ${ }^{105}$ In another report, Yahyyā b. Khāqān was imprisoned under the supervision of Ahmad b. Hishām. ${ }^{106}$ Ahmmad b. Hishām is also reported to have been al-Ma'mūn's hājib. ${ }^{107}$

12. Shabīb b. Humayd b. Qahțaba: Shabīb b. Humayd b. Qạ̣țaba was the haras chief of the Caliph al-Ma'mūn. Al-Ma'mūn later appointed him governor of Qūmis, and Harthama b. A'yan was appointed haras chief in his stead. Command of the haras was later placed in the hands of 'Abd al-Wāhiid b. Salāma al-Ṭaḥlāzī ${ }^{108}$ a relative of Harthama, and after him 'Alī b. Hishām headed the haras. Eventually, al-Ma'mūn executed 'Alī b. Hishām and appointed 'Ujayf b. 'Anbasa as haras chief. ${ }^{109}$

${ }^{102}$ Khalīfa b. Khayyāț, Ta'rīkh, p. 436; al-Jahshiyārī, Kitāb al-wuzarā', p. 124. He was also in charge of the seal during the caliphate of Hārūn al-Rashīd: al-Jahshiyārī, Kitāb al-wuzarā', p. 177.

${ }^{103}$ Khalîfa b. Khayyāt, Ta 'rīkh, p. 438; al-Ṭabarī, Ta'rīkh, third series I, p. 517 (English translation: XXIX, p. 234).

${ }^{104}$ Al-Jahshiyārī, Kitāb al-wuzarā', p. 154; Khalīfa b. Khayyāt, Ta 'rīkh, p. 443. Abū 'Ubayd Allāh, his father, was one of the viziers of al-Mahdī. See: Moscati, "Abū 'Ubayd Allāh," in $E I^{2}$. For more on Abū 1-'Abbās al-Ṭūsī and 'Abd Allāh b. Abī l-'Abbās al-Ṭūsī see: Crone, Slaves on Horses, p. 174.

${ }^{105}$ Al-Maqrīzī, al-Muqaffā, IV, pp. 345-46.

${ }^{106}$ Ibn Hamdūn, al-Tadhkira al-hamdūniyya, p. 302.

${ }^{107}$ Al-Ya'qūbī, Ta'rìkh, II, p. 470.

${ }^{108}$ The nisba al-Ṭahlāzī, which I have found only in this source, is probably written erroneously.

${ }^{109}$ Al-Ya'qūbī, Ta'rīkh, II, 470; Crone, Slaves on Horses, pp. 178, 188-89. 


\section{Bibliography}

Primary sources

Abū l-Faraj al-Ișfahān̄̄, 'Alī b. al-Ḥasan, Kitāb al-aghān̄̄, Beirut, Dār al-Fikr, 1997.

Al-'Askarī, al-Ḥasan b. 'Abd Allāh, al-Awā'il, Beirut, Dār al-Kutub al-'Ilmiyya, 1987.

Al-Balādhurī, Aḥmad b. Yaḥyā, Ansāb al-ashrāf, III, 'Abd al-‘Az̄̄z al-Dūrī (ed.), Wiesbaden, Franz Steiner, 1978.

Al-Balādhurī, Aḥmad b. Yaḥyā, Ansāb al-ashrāf, IVa, Max Schloessinger and M.J. Kister (eds.), Jerusalem, Magnes Press, 1971.

Al-Balādhurī, Aḥmad b. Yahyā, Ansāb al-ashrāf, IVb, Max Schloessinger (ed.), Jerusalem, University Press, 1938.

Al-Balādhurī, Aḥmad b. Yahyyā, Ansā̄b al-ashrāf, V, S.D.F. Goitein (ed.), Jerusalem, University Press, 1936.

Al-Balādhurī, Aḥmad b. Yaḥyā, Ansā̄b al-ashrāf, VIb, Khalil Athamina (ed.), Jerusalem, The Hebrew University of Jerusalem, 1993.

Al-Balādhurī, Aḥmad b. Yaḥyā, Ansāb al-ashrāf, Maḥmūd al-Firdaws al-'Aẓm (ed.), Damascus, Dār al-Yaqza al-'Arabiyya, 2000.

Al-Balādhurī, Aḥmad b. Yaḥyā, Futūḥ al-buldān, 'Abd Allāh Anīs al-Ṭabbā' and 'Umar Anīs al-Ṭabbā' (eds.), Beirut, Mu’ssasat al-Ma‘ārif, 1987.

Al-Bukhārī, Muḥammad b. Ismā‘īl, Șaḥịh al-Bukhārī, Damascus, Dār Ibn Kathīr, 1987.

Al-Dīnawarī, Abū Ḥan̄ifa Aḥmad b. Dāwūd, al-Akhbār al-ṭiwāl, 'Umar Farūq alȚabbā' (ed.), Beirut, Dār al-Arqam, 1995.

Ibn 'Abd Rabbihi, Aḥmad b. Muḥammad, al-'Iqd al-farìd, Mufìd Muhammad Qumayha (ed.), Beirut, Dār al-Kutub al-'Ilmiyya, 1987.

Ibn Abī Shayba, 'Abd Allāh b. Muhammad, al-Mușannaf li-Ibn Abī Shayba, Muhammad 'Awwama (ed.), Jedda, Dār al-Qibla, 2006.

Ibn al-'Adīm, Kamāl al-Dīn, Bughyat al-talab fì ta'rīkh Halab, Suhayl Zakkār (ed.), Beirut, Dār al-Fikr, 1988.

Ibn 'Asākir, 'Alī b. al-Hasan, Ta'rīkh madīnat Dimashq, Muhibb al-Dīn Abū Sa'īd 'Alī b. Gharāma (ed.), Beirut, Dār al-Fikr, 1998.

Ibn al-Athīr, 'Izz al-Dīn, al-Kāmil fì l-ta'rīkh, Abū l-Fidā' 'Abd Allāh al-Qāḍ̄̄ (ed.), Beirut, Dār al-Kutub al-'Ilmiyya, 1987.

Ibn Durayd, Muhammad b. al-Hasan, al-Ishtiqāq, 'Abd al-Salām Muhammad Hārūn (ed.), Egypt, Maktabat al-Khānj̄i,1958.

Ibn Faḍl Allāh al-'Umarī, Aḥmad b. Yaḥyā, Masālik al-abṣār fì mamālik al-amṣār, Beirut, Dār al-Kutub al-'Ilmiyya, 2010.

Ibn Ḥabīb, Kitāb al-muhabbar, Ilse Lichtenstädter (ed.), Beirut, Dār al-Āfāq alJadīda, 1942. 
Ibn Ḥajar al-'Asqalānī, Aḥmad b. 'Alī, Fatḥ al-bārī bi-sharḥ ṣaḥịh al-Bukhārī, 'Abd al-'Az̄̄z b. 'Abd Allāh b. Bāz (ed.), Beirut, Dār al-Fikr, 1993.

Ibn Ḥamdūn, Muḥammad b. al-Ḥasan, al-Tadhkira al-ḥamdūniyya, Iḥsān 'Abbās and Bakr 'Abbās (eds.), Beirut, Dār Șādir, 1996.

Ibn 'Idhārī, Muḥammad, Kitāb al-bayān al-mughrib fì akhbār al-Andalus wa-lMaghrib, Leiden, Brill, 1948.

Ibn Kathīr, Abū l-Fidā’ Ismā'īl, al-Bidāya wa-l-nihāya, Beirut, Dār Ibn Kathīr, 2007.

Ibn Khallikān, Aḥmad b. Muḥammad, Wafayāt al-a 'yān wa-anbāa' abnā' alzamān, Iṇsān 'Abbās (ed.) Beirut, Dār al-Thaqāfa, 1972.

Ibn al-Nadīm, Muḥammad b. Isḥāq, al-Fihrist li-Ibn al-Nadīm, Cairo, al-Maṭba'a al-Raḥmāniyya, 1969.

Ibn Sa'd, Muḥammad, al-Tabaqāt al-kubrā: al-qism al-mutammim li-tābi ‘ $\mathrm{l}$ ahl al-Madīna wa-man ba'dahum, Ziyād Muḥammad Manșūr (ed.), Medina, Maktabat al-'Ulūm wa-1-Hikam, 1987.

Al-Jahshiyārī, Muḥammad b. 'Abdūs, Kitāb al-wuzarā' wa-l-kuttāb, Mușțafā 1Saqqā et. al. (ed.), Cairo, Muștafā l-Bābī l-Ḥalabī, 1938.

Al-Jumaḥ̄̄, Muḥammad b. Sallām, Ṭabaqāt fuḥūl al-shu 'arā', Maḥmūd Muḥammad Shākir (ed.), Jedda, Dār al-Madanī, 1980.

Khalīfa b. Khayyāt, Ta 'rīkh Khalīfa b. Khayyāt, Akram Diyā' al-'Umarī (ed.), Riyadh, Dār Țayba, 1985.

Al-Kindī, Muḥammad b. Yūsuf, Wulāt Miṣr, Ḥusayn Nașṣār (ed.), Beirut, Dār Șādir, n.d.

Al-Maqrīzī, Aḥmad b. 'Alī, al-Muqaffā l-kabīr, Muḥammad al-Ya'lāwī (ed.), Beirut, Dār al-Gharb al-Islāmī, 1991.

Al-Mizzī, Yūsuf b. al-Zakī 'Abd al-Raḥmān, Tahdhīb al-kamāl fì asmā' al-rijāl, Bashshār 'Awwād Ma'rūf (ed.), Beirut, Mu'assasat al-Risāla, 1992.

Al-Qalqashandī, Ahmmad b. 'Alī, Șubḥ al-a 'shā fi șinā 'at al-inshā', Muhammad Husayn Shams al-Dīn (ed.), Beirut, Dār al-Fikr, 1987.

Al-Samhūdī, 'Alī b. 'Abd Allāh, Wafā' al-wafā bi-akhbār dār al-Muștafā, Qāsim al-Sāmarrā'ī (ed.), London-Jedda, al-Furqān, 2001.

Al-Ṣan‘ānī, 'Abd al-Razzāq, al-Muṣannaf, Ḥabīb al-Raḥmān al-A ‘ẓamī (ed.), Beirut, al-Majlis al-'Ilmī, 1970.

Al-Ṭabarī, Muhammad b. Jarīr, Ta’ rīkh al-rusul wa-l-mulūk, M.J. de Goeje (ed.), Leiden, Brill, 1879-1901.

Al-Ṭabarī, Muhammad b. Jarīr, The History of al-Tabarī, XVII, G.R. Hawting (trans.), Albany, State University of New York, 1996.

Al-Ṭabarī, Muhammad b. Jarīr, The History of al-Ṭabarī, XVIII, M.G. Morony (trans.), Albany, State University of New York, 1987.

Al-Ṭabarī, Muhammad b. Jarīr, The History of al-Ṭabarī, XXI, Michael Fishbein (trans.), Albany, State University of New York, 1990.

Al-Ṭabarī, Muhammad b. Jarīr, The History of al-Tabarī, XXII, Everett K. Rowson (trans.), Albany, State University of New York, 1989. 
Al-Ṭabarī, Muhammad b. Jarīr, The History of al-Tabarī, XXIII, Martin Hinds (trans.), Albany, State University of New York, 1990.

Al-Ṭabarī, Muḥammad b. Jarīr, The History of al-Tabarī, XXV, Khalid Yahya Blankinship (trans.), Albany, State University of New York, 1989.

Al-Ṭabarī, Muhammad b. Jarīr, The History of al-Ṭabarī, XXVI, Carole Hillenbrand (trans.), Albany, State University of New York, 1989.

Al-Ṭabarī, Muhammad b. Jarīr, The History of al-Ṭabarī, XXVII, John Alden Williams (trans.), Albany, State University of New York, 1985.

Al-Ṭabarī, Muhammad b. Jarīr, The History of al-Ṭabarī, XXVIII, Jane Dammen McAuliffe (trans.), Albany, State University of New York, 1995.

Al-Ṭabarī, Muhammad b. Jarīr, The History of al-Ṭabarī, XXIX, Hugh Kennedy (trans.), Albany, State University of New York, 1990.

Al-Ṭabarī, Muhammad b. Jarīr, The History of al-Tabarī, XXX, C.E. Bosworth (trans.), Albany, State University of New York, 1989.

Wakī', Muḥammad b. Khalaf, Akhbār al-quḍāt, Beirut, 'Ālam al-Kutub, 1992.

Al-Ya'qūbī, Aḥmad b. Abī Ya'qūb, Ta 'rīkh al-Ya 'qūbī, Beirut, Dār Șādir, 1960.

Secondary sources

Athamina, Khalil, "Non-Arab Regiments and Private Militias during the Umayyad Period," Arabica, 45, 3 (1998), pp. 347-378.

Bearman, P.J. et al., “"Asas,” in P.J. Bearman et al., Encyclopcedia of Islam, 2nd edition, Leiden, Brill, 1960-2005.

Cobb, P.M., “"Umar (II) b. 'Abd al- 'Azīz,” in P.J. Bearman et al., Encyclopcedia of Islam, 2nd edition, Leiden, Brill, 1960-2005.

Crone, Patricia, "Mawlā," in P.J. Bearman et al., Encyclopcedia of Islam, 2nd edition, Leiden, Brill, 1960-2005.

Crone, Patricia, Slaves on Horses: The Evolution of the Islamic Polity, Cambridge, Cambridge University Press, 1980.

Crone, Patricia, "The Significance of Wooden Weapons in Al-Mukhtār's Revolt and the 'Abbasid Revolution," in I.R Netton (ed.), Studies in Honour of Clifford Edmund Bosworth, Leiden, Brill, 1999-2000, pp. 174-187.

Darādkeh, Șāliḥ, "al-Ḥaras wa-l-shurța fị șadr al-Islām ilā nihāyat al-dawla alumawiyya," Dirāsāt (Amman), 14, 4 (1987), pp. 69-95.

Donner, Fred M. (ed.), The Articulation of Early Islamic State Structures: The Formation of the Classical Islamic World, Farnham, Ashgate, 2012, pp. xiii-xliv.

Donner, Fred M., "The Shurța in Early Umayyad Syria," in M. Adnan Bakhit and Robert Schick (eds.), The Fourth International Conference on the History of Bilād al-Shām During the Umayyad Period, Proceedings of the 
Third Symposium, Amman, University of Jordan, 1989, English section, pp. 247-262.

Ebstein, Michael, "Shurța Chiefs in Bașra in the Umayyad Period: A Prosopographical Study," Al-Qantara, 31, 1 (2010), pp. 103-147.

Elad, A., "Community of Believers of 'Holy Men' and 'Saints' or Community of Muslims? The Rise and Development of Early Muslim Historiography," Journal of Semitic Studies, 47, 2 (2002), pp. 241-308.

Elgood, R., "Arms and armour," in G. Krämer, E. Rowson, J. Nawas y D. Matringe, Encyclopcedia of Islam Three, Leiden, Brill, 2007-.

Hasson, Isaac, "Les mawālī dans l'armée musulmane sous les premiers Umayyades," Jerusalem Studies in Arabic and Islam, 14 (1991), pp. 176-213.

Hawting, G.R., "al-Mukhtār b. Abī 'Ubayd," in P.J. Bearman et al., Encyclopcedia of Islam, 2nd edition, Leiden, Brill, 1960-2005.

Hawting, G.R., "Khāâlid b. 'Abd Allāh al-Kasri," in P.J. Bearman et al., Encyclopcedia of Islam, 2nd edition, Leiden, Brill, 1960-2005.

Hoyland, Robert G. and Gilmour, Brian, Medieval Islamic Swords and Swordmaking: Kindi's treatise "On swords and their kinds, "Warminster, Gibb Memorial Trust, 2006.

Husayn, Falih, "The Participation of non-Arab Elements in the Umayyad Army and Administration," in Fred M. Donner (ed.), The Articulation of Early Islamic State Structures: The Formation of the Classical Islamic World, Farnham, Ashgate, 2012, pp. 265-289.

Ibn al-Nadīm, The Fihrist of al-Nadīm: a tenth century survey of Muslim culture, Bayard Dodge (trans.), New York, Columbia University Press, 1970.

Kennedy, Hugh, The Armies of the Caliphs: Military and Society in the Early Islamic State, London, Routledge, 2001.

Kister, M.J., "The Battle of the Harra: Some Socio-Economic Aspects," in Myriam Rosen Ayalon (ed.), Studies in Memory of Gaston Wiet, Jerusalem, The Hebrew University of Jerusalem, 1977, pp. 33-49, available on: $<$ http://www.kister.huji.ac.il/content/battle-\%E1\%B8\%A5arra-some-socioeconomic-aspects $>$ [last consulted 31 March 2015].

Landau Tasseron, Ella, "Alliances in Islam," in Monique Bernards and John Nawas (eds.), Patronate and Patronage in Early and Classical Islam, Leiden, Brill, 2005, pp. 1-50.

Lecker, Michael, “'Amr ibn Hazm al-Anșārī and Qur'ān 2,256: 'No Compulsion Is There in Religion'," Oriens, 35 (1996), pp. 57-64.

Lecker, Michael, "The Prosopography of Early Islamic Administration," Jerusalem Studies in Arabic and Islam, 34 (2008), pp. 529-533.

Lévi-Provençal, Evariste, "Mūsā b. Nușayr," in P.J. Bearman et al., Encyclopcedia of Islam, 2nd edition, Leiden, Brill, 1960-2005.

Marsham, Andrew, Rituals of Islamic Monarchy: Accession and Succession in the First Muslim Empire, Edinburgh, Edinburgh University Press, 2009. 
Morony, M.G., Iraq after the Muslim Conquest, Piscataway, Gorgias Press, 2005.

Moscati, S., "Abū Muslim," in P.J. Bearman et al., Encyclopcedia of Islam, 2nd edition, Leiden, Brill, 1960-2005.

Moscati, S., “Abū 'Ubayd Allāh,” in P.J. Bearman et al., Encyclopcedia of Islam, 2nd edition, Leiden, Brill, 1960-2005.

Nielsen, J.S., "Shurța," in P.J. Bearman et al., Encyclopcedia of Islam, 2nd edition, Leiden, Brill, 1960-2005.

Noth, Albrecht, The Early Arabic Historical Tradition: A Source-Critical Study, Princeton, Darwin Press, 1994.

Pedersen, J., "Masdjid," in P.J. Bearman et al., Encyclopcedia of Islam, 2nd edition, Leiden, Brill, 1960-2005.

Pellat, Ch., "Harthama b. A 'yan," in P.J. Bearman et al., Encyclopcedia of Islam, 2nd edition, Leiden, Brill, 1960-2005.

Al-Qāḍ̂̄, Wadād, "Security Positions under the Umayyads: The Story of 'Ma 'bad al-Turuq" in Heinrich Biesterfeld and Verena Klemm (eds.), Difference and Dynamism in Islam. Festschrift for Heinz Halm on his 70th Birthday, Würzburg, Ergon-Verl, 2012, pp. 253-283.

Rashid, A.M., The Role of the Shurța in Early Islam, Ph.D. Dissertation, Edinburgh, 1983.

Robinson, C.F., "Neck-Sealing in Early Islam," Journal of the Economic and Social History of the Orient, 48 (2005), pp. 401-441.

Sourdel, D., "Ibn Māhān, 'Alī b. 'Īsā b. Māhān," in P.J. Bearman et al., Encyclopcedia of Islam, 2nd edition, Leiden, Brill, 1960-2005.

Sourdel, D., "Khalīfa," in P.J. Bearman et al., Encyclopcedia of Islam, 2nd edition, Leiden, Brill, 1960-2005.

Stone, Lawrence, "Prosopography," in Felix Gilbert and Stephen R. Graubard (eds.), Historical Studies Today, New York, W.W. Norton, 1972, pp. 107-140.

The Jerusalem Prosopography Project: The Prosopography of the Early Islamic Administration, available on: <www.micro5.mscc.huji.ac.il:81/JPP/v3> [last consulted 31 March 2015].

Tyan, Emily, Histoire de l'organisation judiciaire en pays d'Islam, Leiden, Brill, 1960.

Wellhausen, J., Das Arabische Reich und sein Sturz, Berlin, G. Reimer, 1902.

Wellhausen, J., The Arab Kingdom and its Fall, Margaret Graham Weir (trans.), London, Curzon, 1973.

Zetterstéen, K.V., ““Amr b. Sa'īd b. al-'Āṣ b. Umayya al-Umawī, known as alAshdak," in P.J. Bearman et al., Encyclopcedia of Islam, 2nd edition, Leiden, Brill, 1960-2005.

Recibido: $17 / 04 / 2013$

Aceptado: 16/12/2014 